\title{
Relações entre a Autistic Behavior Checklist (ABC) e o perfil funcional da comunicação no espectro autístico****
}

\author{
Relations between the Autistic Behavior Checklist (ABC) and the \\ functional communicative profile
}

Fernanda Dreux Miranda Fernandes* Liliane Perroud Miilher**

\author{
*Fonoaudióloga. Professor Associado \\ do Curso de Fonoaudiologia da \\ Faculdade de Medicina da \\ Universidade de São Paulo. Presidente \\ da Sociedade Brasileira de \\ Fonoaudiologia. Endereço para \\ correspondência: \\ R. Cipotânea, 51 - Campus Cidade \\ Universitária - São Paulo - SP - CEP \\ 05360-160 (fernandadreux@usp.br). \\ **Fonoaudióloga. Mestranda em \\ Ciências da Reabilitação, Área de \\ Concentração Comunicação Humana da \\ Faculdade de Medicina da \\ Universidade de São Paulo. \\ ***Trabalho Realizado no Laboratório \\ de Investigação Fonoaudiologica nos \\ Distúrbios do Espectro Autístico - \\ Departamento de Fonoaudiologia, \\ Fisioterapia e Terapia Ocupacional da \\ Faculdade de Medicina da \\ Universidade de São Paulo (Fapesp \\ Projeto 2005/04113-8)
}

Artigo Original de Pesquisa

Artigo Submetido a Avaliação por Pares

Conflito de Interesse: não

Recebido em 22.08.2007. Revisado em 9.05.2008. Aceito para Publicação em 9.05.2008.

\begin{abstract}
Backgroud: language and communication disorders are proposed as one of the three fundamental criteria for the description or diagnosis of pervasive developmental disorders (PDD), along with social disabilities and a narrow focus of interest. This way, the determination of simple procedures that can be used by health and education professionals to identify the persons that need specialized services is essential. The Autistic Behavior Checklist (ABC) is being used in several studies because it allows simple application and may be based on filmed behavior samples, interviews with parents or therapists. Its' results, on the other side, had been tested for a few decades and been shown reliable. Aim: the general aim of this study is to verify the possibility that the assessment of the relation between communicative profile and the $A B C$ score contributes to the diagnostic process of persons with disorders of the autistic spectrum. Method: subjects were 117 children and adolescents with ages between 2 and 16 years attending language therapy. Results: were statistically analyzed and indicated that there are negative correlations between the $A B C$ scores and communicative interaction and complexity. The small amount of correlations between language sub-scale and the other data suggest that there is a dissociation of the description provided by the ABC and the criteria proposed by the DSM-IV and the ICD-10 to the diagnosis of autism. Conclusion: the search for objective criteria to determine subgroups of the autistic spectrum remains a challenge.
\end{abstract}

Key Words: Child; Language; Autistic Disorder.

\section{Resumo}

Tema: as alterações de comunicação e linguagem têm sido propostas como um dos três elementos fundamentais para a caracterização e o diagnóstico dos distúrbios globais do desenvolvimento (DGD). A Autistic Behavior Checklist (ABC) tem sido utilizada em diversas pesquisas, pois possibilita uma aplicação simples, que pode ser realizada a partir de amostras filmadas de comportamento, entrevistas com pais ou terapeutas, e pode ser utilizada por profissionais das áreas da saúde e da educação. Objetivo: a proposta deste estudo envolve a verificação das correlações entre o perfil funcional da comunicação e as diferentes pontuações na ABC. O objetivo geral desta pesquisa é identificar a possibilidade de contribuição da avaliação fonoaudiológica de crianças e adolescentes incluídos no espectro autístico a partir da verificação de relações entre seu desempenho comunicativo e a pontuação obtida na ABC. Método: foram sujeitos desta pesquisa 117 crianças e adolescentes, entre 2 e 16 anos de idade, já atendidos ou em atendimento no Laboratório de Investigação Fonoaudiológica em Distúrbios Psiquiátricos da Infância do Curso de Fonoaudiologia da Faculdade de Medicina da USP. Resultados: indicaram a existência de correlações negativas entre a pontuação na $\mathrm{ABC}$ e a interatividade e complexidade da comunicação. As poucas correlações entre a sub-escala de linguagem e os outros dados sugerem a dissociação entre a descrição propiciada pela ABC e os critérios sugeridos pelo DSM-IV e pela CID-10 para o diagnóstico de autismo. Conclusão: a busca de critérios objetivos para a determinação de sub-grupos no espectro autístico permanece um desafio.

Palavras-Chave: Transtorno Autístico; Linguagem; Criança. 


\section{Introduction}

The concept of autistic spectrum is being proposed as a way of including the various global developmental disorders in an articulate perspective that includes the complex interrelations between the different clinic pictures and not only placing them side by side (1). The questions of language related to the psychiatric disorders included within the autistic spectrum have been object of previous reviews (2-3) and detailed descriptions (4).

The recent perspectives consider that probably there is a genetic component involved at the origin of the autistic features (5) that are considered as a behavioral syndrome with variable symptoms according to the age and interventions (6).

An important point of this discussion is also marked by the criteria proposed by IDC- 10 and by DSM-IV that indicate the need of "qualitative damages" in each of the great areas studied. This observation refers to the great phenotypic variety observed, where criteria of presence or absence of symptoms wouldn't be enough to describe each clinical case (7-9). A large part of the researches involved on the description of the different clinical pictures that are part of the autistic spectrum emphasizes the need of multidisciplinary perspectives for diagnosis (9). The search for better diagnostic criteria has generated several studies (10-14).

The Autism Behavior Checklist (ABC), composes the Autism Screening Instrument for Educational Planning (ASIEP) (15).It is a scale of non-adaptable behaviors, created to scan and indicate the probability of autism diagnostic. It has been validated in Brazil (16) and has been widely used at academic and institutional contexts. (Attached). Otherwise, there is not unanimous agreement about the values indicated in that proposal, they are considered too high tending to not classify an important portion of children (17).

It is important to underline the fact that non verbal children do not take points at the items that refers to expressive language inside the subscale of language. This represents an important bias for diagnostic. This took several authors to consider the $A B C$ a scale with high specificity, in other words, it does not includes non autistic individuals, and tends to do not include many autistic individuals $(13,15,17,18,23)$.

The performance in functional activities of communication was the best indicator of the future performance (19), in a study that investigates the progress of children attended at specialized schools.

The proposal of this study involves the verification of hypothesis that it is possible to identify correlations between the functional profile of communication of children and teenagers with psychiatric diagnostics included in the autistic spectrum and their scores at ABC.

\section{Objective}

The objective of this research is to determinate the existence of correlations between the functional profile of communication of children and teenagers with psychiatric diagnostics included in the autistic spectrum and their scores at ABC.

\section{Methods}

\section{Subjects}

The subjects of this research were 117 children and teenagers between 2 and 16 years (average 7.8 y.). All of them were or have been patients of the Laboratory of Language Pathology Investigation in Infantile Psychiatric Disorders of the course of Language Pathology of Medicine School, University of Sao Paulo (USP). Parents or responsible signed the consent form approved by the ethic commission of the institution. (Cappesq460/02)

\section{Procedures}

The videotape recordings realized during the process of construction of a data basis for evaluations realized at the Laboratory of Language Pathology Investigation in Infantile Psychiatric Disorders of the course of Language Pathology of Medicine School, USP were analyzed.

These records register 30 minutes of interaction between the subject and the language pathologist in play situations with the material chosen by each subject.

The tapes were analyzed by the researcher, by the language pathologist that conducted the assessment of each of the subjects and by a third judge, a scholarship student with technical capacitating for a guarantied the fidelity of the results. The data were registered in an individual specific protocol (Attached) and resumed in digitalized planeloads of data.

For the application of $\mathrm{ABC}$ the data were complemented by interviews with parents and therapists. 
For the statistic study the Spearmen correlation analysis was applied with the objective of verification of the level of relation between the variables. The significance level determined was $5 \%$.

\section{Results}

In what refers to the functional communication profile, only the communicative functions "Narrative" and "Consent Request" do not figure between the most frequently expressed by none of the subjects.

Table 1 shows the value that refers to each one of the sub-scales and the total score at $\mathrm{ABC}$ of the whole group of subjects.

The analysis of correlation between the studied aspects was realized trough the Spearman correlation analysis and also used indexes of significance of $5 \%$.

Table 2 shows the most significant results of correlation between the functional communicative profile and the results of the application of $\mathrm{ABC}$, in each one of the sub-scales and in their partial results.

Table 3 shows the significant values of the correlation between the total scores in each of the sub-scales of $\mathrm{ABC}$ and the communicative functions expressed with higher frequency by the subjects of this study.

TABLE 1. ABC's subscales and total scores averages

\begin{tabular}{c|cccccccc}
\hline & SS & RE & BO & LG & PS & Total \\
\hline Minimum & 0 & 0 & 0 & 0 & 0 & 0 \\
Maximum & 23 & 34 & 28 & 21 & 17 & 95 \\
Average & 3.17 & 14.07 & 7.01 & 6.76 & 6.04 & 37.07 \\
Standard-deviation & 3.88 & 6.52 & 6.54 & 5.01 & 4.2 & 17.54 \\
\hline
\end{tabular}

Legend: $\mathrm{SS}=$ sensorial stimulus; $\mathrm{RE}=$ relationship; $\mathrm{BO}=$ use of body and objects; $\mathrm{LG}=$ language; PS = personal-social development.

TABLE 2. ABC scores and Functional Communicative Profile - significant correlations

\begin{tabular}{|c|c|c|c|c|c|c|}
\hline & ABC-SS & ABC-RE & $\mathrm{ABC}-\mathrm{BO}$ & ABA - LG & $\mathrm{ABC}-\mathrm{PS}$ & $\mathrm{ABC}-$ total \\
\hline Subject- acts & & & & 0.003 & & \\
\hline Acts/minute & & & & 0.025 & 0.031 & \\
\hline $\mathrm{G}$ & 0.001 & 0.018 & 0.001 & $0.043(-)$ & 0.044 & 0.045 \\
\hline $\mathrm{Ve}$ & $0.013(-)$ & & $0.002(-)$ & 0.044 & & \\
\hline \multicolumn{7}{|l|}{ Vo } \\
\hline IF & $<0.001(-)$ & $0.002(-)$ & $0.003(-)$ & & & $0.001(-)$ \\
\hline NIF & $<0.001$ & 0.001 & 0.006 & & & 0.001 \\
\hline
\end{tabular}

Legend: $\mathrm{ABC}=$ Autism Behavior Checklist $\mathrm{SS}=$ sensorial stimulus; $\mathrm{RE}=$ relationship $; \mathrm{BO}=$ use of body and objects; $\mathrm{LG}=$ language PS $=$ personal-social development; $\mathrm{G}=$ gestual; $\mathrm{Ve}=$ verbal; $\mathrm{Vo}=$ vocal; $\mathrm{IF}=$ interactive functions; $\mathrm{NIF}=$ non-interactive functions.

TABLE 3. ABC and Communicative functions - significant correlations

\begin{tabular}{|c|c|c|c|c|c|}
\hline & $\mathrm{ABC}-\mathrm{SS}$ & $\mathrm{ABC}-\mathrm{RE}$ & $\mathrm{ABC}-\mathrm{BO}$ & $\mathrm{ABC}-\mathrm{PS}$ & $\mathrm{ABC}-$ total \\
\hline XP & & & \multicolumn{3}{|c|}{0.009} \\
\hline NF & & 0.032 & 0.001 & & 0.001 \\
\hline $\mathrm{AR}$ & & & \multicolumn{3}{|c|}{$0.044(-)$} \\
\hline PR & & & 0.04 & & \\
\hline LA & & $0.022(-)$ & $0.048(-)$ & & \\
\hline $\mathrm{CO}$ & $<0.001(-)$ & $0.066(-)$ & $<0.001(-)$ & $0.001(-)$ & $<0.001(-)$ \\
\hline SO & & & & & $0.033(-)$ \\
\hline
\end{tabular}

Legend: $\mathrm{ABC}=$ Autism Behavior Checklist; $\mathrm{SS}=$ sensorial stimulus; $\mathrm{RE}=$ relationship; $\mathrm{BO}=$ use of body and objects; $\mathrm{PS}=$ personal-social development; $\mathrm{XP}=$ exploratory; $\mathrm{NF}$ - non-focused; $\mathrm{AR}=$ action request $\mathrm{PR}=$ protest $\mathrm{LA}=$ labeling; $\mathrm{CO}=\mathrm{comment} ; \mathrm{SO}=$ show-off. 


\section{Discussion}

It was possible to observe that only the functions "Narrative" and "Consent Request" do not figure between the most frequent for none of the studied subjects. Both can be associated to the need of meta-presentation, because they demand at least some comprehension about the variable role of the interlocutors. In this way their absence can be related to the difficulties of metapresentation and Theory of Mind, frequently associated to the features of the autistic spectrum $(1,4,12)$. It also became evident the huge individuals variations mentioned at literature for many decades (11,14,19-20,23).

At table 1, the possibility of absence of scores in some of the sub-scales, on the other hand, may indicate difficulties relative to translation and/or to the application of the protocol. Despite the attempts to control the possibility, through the utilization of filmed material, and parents and therapists interviews $(11,19-20)$ it is possible that the research of behaviors in terms of only presence and absence (8,21-22) had taken all to look for identifying any possibility of occurrence of each one of the behaviors.

The data at Table 2 indicate that the correlations of the total result are positive with the use of the gestual communicative mean and with the expression of non-interactive communicative functions and negative with more interactive communicative functions. That is, the better functional communicative profile, smaller the $\mathrm{ABC}$ scores. All the significant correlations of the use of interactive communicative functions are negative, while they are positive for the use of non-interactive communicative functions. These data can suggest that there is consistency at the association between the use of non-interactive functions and the autistic spectrum diagnostic (10), although this it is not an $\mathrm{ABC}$ criterion. The positive correlation between the uses of verbal communication and the language sub-scale (the better the verbal communication, the higher the ABC scores), seems to confirm the weak relation between it and the autism diagnostic mentioned before $(6,15)$.

The lack of correlations with the language subscale as verified at Table 3 , seems one more time to indicate the weak relation between the items of this sub-scale and the language disorders observed in individuals of the autistic spectrum (17). On the other hand, the negative correlation with the interactive communicative functions and positive with the non-interactive ones, suggests again the functional characterization of the language disorders of the autistic spectrum.

\section{Conclusion}

The present study proposed the determination of the existence of correlations between the functional communicative profile of children and adolescents with psychiatric diagnostics included in the autistic spectrum and their scores at the ABC. Generically, data indicated negative correlation between the interactivity of communication and the use of verbal communicative mean and the scores at sub-scales of Sensorial Stimulation and Use of Body and Objects. The results indicate proportionally more correlations between the total results and each of the sub-scales of $\mathrm{ABC}$ and the aspects involving communication interactivity and the communicative means used than to the use of certain communicative functions. In what refers to each of the sub-scales the absence of correlations between the Language sub-scale and communicative functions is emphasized. On the other hand, also deserves attention the negative correlation between scores on all sub-scales, except Language, of the $\mathrm{ABC}$ and the use of Comment communicative function. These data seem to indicate that there is a significant correlation between the $\mathrm{ABC}$ scores and the results referring to the functional communication profile, except on the Language sub-scale. For sure this constitute a strong argument in favor of the complementarily use of the $\mathrm{ABC}$ and the determination of the functional communicative profile in the diagnosis of autistic spectrum individuals.

The large number of subjects in this research and the fact that all of them had psychiatric diagnosis included in the autistic spectrum, according to the ICD-10 criteria or DSM-IV, argue in favor of studies that question the value of the $\mathrm{ABC}$ utilization as diagnostic criteria for autism. The results reinforce the notion that there is no agreement between the diagnostic description proposed by the $\mathrm{ABC}$ and the criteria suggested by DSM-IV and ICD-10.

In this way, at the lack of psychiatric diagnostics, it is suggested that the application of $\mathrm{ABC}$ can confirm the diagnostics hypotheses, but must do not function as the only one instrument of determination of therapeutic choices. 


\section{References}

1. Klin A. Asperger syndrome: an update. Rev Bras Psiquiatr 2003;25(2):103-9.

2. Fernandes FDM. Sistematização de dados referentes à atuação fonoaudiológica em hospital-dia infantil - o perfil comunicativo como indicador do desempenho. Pró-Fono Revista de Atualização Científica 2000;12(1):1-9.

3. Fernandes FDM. Perfil comunicativo, desempenho sociocognitivo, vocabulário e meta-representação em crianças com transtorno do espectro autístico. Pró-Fono Revista de Atualização Científica. 2003;15(3):267-78

4. Belkadi A. Language impairments in autism: evidence against mind-blindness. SOAS Working Papers in Linguistic. 2006;14:3-13

5. Carvalheira G, Vergani N, Brunoni D. Genética do autismo. Rev Bras Psiquiatr. 2004; 26(4): 270-272.

6. Young EC, Diehl JJ, Morris D, Hyman SL, Benneto L. The use of two language tests to identify pragmatic language problems in children with autism spectrum disorders. Language, Speech and hearing service in school. 2005;36:62-72.

7. Bryson SE, Rogers SJ, Fombonne E. Autism Spectrum Disorders: early detection, intervention, education and psychopharmacological management. Can J Psychiatry. 2003;48(8):506-16.

8. Filipek PA, Steinberg-Epstein R, Book TM. Intervention for Autism Spectrum Disorders. Neuro RX. 2006;3:20716.

9. Tidmarsh L, Volkmar FR. Diagnosis and epidemiology of autism spectrum disorders. Can J Psychiatry. 2003;48(8):517-25.

10. Boser K, Higgins S, Fetherston A, Preissler MA, Gordon B. Semantic Fields in Low-Functioning Autism. J Autism Develop Disord 2002;32(6):563-82.

11. Sperry LA, Symons FJ. Maternal judgments of intentionality in young children with autism: The effects of diagnostic information and stereotyped behavior. J Autism Develop Disord 2003;33(3):281-7.

12. Losh M, Capps L. Narrative ability in high-functioning children with autism or Asperger's syndrome. J Autism Develop Disord 2003;33(3):239-51.
13. Bildt A, Sytema S, Ketelaars C, Kraijer D, Muldre E, Volkmar F, Minderaa R. Interelationship between Autism Diagnostic Observation Schedule-Generic (ADOS-G), Autism Diagnostic Interview-Revised (ADI-R), and the Diagnostic and Statistical Manual of mental Disorders (DSM-IV-TR) classification ion children and adolescents with mental retardation. J Autism Develop Disord. 2004;24(2):129-37.

14. Paul R, Miles S, Cicchetti D, Sparrow S, Klin A, Volkmar F, Cofflin M, Booker S. Adaptative behavior in autism ans pervasive developmental disorder-not otherwise specified: Microanalysis of scores on the Vineland adaptative behavior scales. J Autism Develop Disord. 2004;34(2):223-8.

15. Miranda-Linné FM, Melin L. A factor analytic study of the Autism Behavior Checklist. J Autism Develop Dis. 2002;32(3):181-8.

16. Marteleto MRF, Pedromônico MRM. Validity of Autism Behavior Checklist (ABC): preliminary study. Rev Bras Psiquiatr. 2005;27(4):295-301.

17. Rellini E, Tortolani D, Trillo S, Carbone S, Montecchi F. Childhood Autism Rating Scale (CARS) and Autism Behavior Checklist (ABC) correspondence and conflicts with DSM-IV criteria in diagnosis of autism. J Autism Develop Dis. 2004:34(6):703-8.

18. Williams J, Brayne C. Screening for autism spectrum disorders. Autism. 2006;10(1):11-35.

19. Charman T, Howlin P, Berry B, Prince E. Measuring developmental progress of children with autism spectrum disorder on school entry using parent report. Autism. 2004;8(1):89-100.

20. Bosseler A, Massaro DW. Development and evaluation of a computer-animated tutor for vocabulary and language learning in children with autism. J Autism Develop Disord. 2003;33(6):653-72.

21. Noland RM, Gabriels RL. Screening and identifying children with autism spectrum disorders in the public school system: The development of a model process. J Autism Develop Disord. 2004;34(3):265-77.

22. Goldberg WA, Osann K, Filipek PA, Laulhere T, Jarvis K, Modahl C, Flodman P, Spence MA. Language and other regression: Assessment and timing. J Autism Develop Disord. 2003;33(6):607-16.

23. Jarrold C, Brock J. To match or not to match? Methodological issued in autism-related research. J Autism Develop Disord. 2004;34(1):81-6. 


\section{Anexo}

III: Autism Behavior Checklist (ABC) (Krug et al., 1980).

Nome:

Avaliador:
Sujeito $\mathrm{N}^{\circ}$

Data:

1. Gira em torno de si por longo período de tempo

2. Aprende uma tarefa, mas esquece rapidamente

3. Raramente atende a estímulos não verbais, sociais, ambientais

4. Ausência de respostas para solicitações verbais (vem cá, senta...)

5. Usa brinquedos inapropriadamente

6. Pobre uso na discriminação visual (fixa partes de objetos)

7. Ausência de sorriso social

8. Uso inadequado de pronomes (inversão pronominal)

9. Insiste em manter certos objetos consigo

10. Parece não escutar (suspeita-se de surdez)

11. Fala monótona e sem ritmo

12. Balança-se por longos períodos de tempo

13. Não estende o braço para ser pego (nem quando era bebê)

14. Reações fortes a mudanças no ambiente

15. Ausência de atenção ao seu nome

16. Gira em torno de si, balança as mãos

17. Ausência de reposta para expressão facial / sentimento dos outros

18. Raramente usa "sim" ou "não"

19. Habilidades em áreas específicas

20. Ausência de repostas a solicitações envolvendo referenciais espaciais

21. Sobressalto a som intenso

22. Balança as mãos

23. Intensos acessos de raiva ou birra

24. Evita ativamente o contato social

25. Resiste ao toque / a ser pego / a carinho

26. Não reage a estímulos dolorosos

27. Difícil ou rígido no colo (mesmo qdo bebê)

28. Flácido quando no colo

29. Aponta para indicar o objeto desejado

30. Anda nas pontas dos pés

31. Machuca os outros, mordendo, batendo..

32. Repete a mesma fresa muitas vezes

33. Não brinca de imitar outras crianças

34. Não pisca para luz forte nos olhos

35. Machuca-se mordendo-se, batendo a cabeça...

36. Não espera para ser atendido (quer as coisas imediatamente)

37. Não aponta mais que cinco objetos

38. Dificuldade em fazer amigos

39. Tapa os ouvidos para vários sons

40. Gira, bate objetos muitas vezes

41. Dificuldade no treino de toalete

42. Usa de 0 a 5 palavras / dia para indicar necessidades

43. Frequientemente muito ansioso ou medroso

44. Franze sobrancelhas, cobre ou vira os olhos com luz natural

45. Não se veste sem ajuda

46. Repete constantemente as mesmas palavras ou sons

47. Olha através das pessoas

\begin{tabular}{l|l|l|l|l} 
ES & RE & CO & LG & PS \\
4
\end{tabular}

4

2

2

2

3

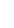

4

4

2

4

1 